\title{
MEDYCZNY ASPEKT LEGALIZACJI MIĘKKICH NARKOTYKÓW - ZAGROŻENIE CZY SZANSA NA SKUTECZNE LECZENIE?
}

\begin{abstract}
Streszczenie. Obecnie temat medycznego zastosowania marihuany poruszany jest publicznie częściej niż w ubiegłych latach. Najnowsze badania kliniczne potwierdzają leczniczy aspekt jej działania na organizm człowieka w walce $\mathrm{z}$ różnymi chorobami, które dotąd nie były możliwe do wyleczenia lub choćby do zmniejszenia ich wyniszczających skutków. Na świecie kolejne kraje dopuszczają obrót konopiami, albo całkowicie, albo jako quasi-legalizację. Polski system prawny nie dopuszcza obecnie wariantu legalizacji cannabis, jednak opinia publiczna wyraża w coraz większym procencie poparcie dla wprowadzenia legalnego używania marihuany do celów medycznych, a instytucje państwowe nawołują rząd do uregulowania tej kwestii. W środowiskach wspierających politykę antynarkotykową mówi się jedynie o negatywnych następstwach zażywania miękkich narkotyków. Warto zrobić bilans korzyści i strat oraz przeanalizować badania, by rozstrzygnąć dylemat - czy marihuana to samo zło, czy może rzeczywiście szansa na skuteczne leczenie?
\end{abstract}

Słowa kluczowe: medyczna marihuana, konopie lecznicze, polityka narkotykowa, lecznicza marihuana, legalizacja.

\section{WPROWADZENIE}

W ostatnim czasie bardzo dużo mówi się o potrzebie stworzenia leków na choroby, które są obecnie niemożliwe do wyleczenia. Coraz częściej w mediach poruszane są tematy dotyczące problemów życia codziennego ludzi cierpiących między innymi na stwardnienie zanikowe boczne (ALS), chorobę Alzheimera czy też padaczkę. Jest również wiele innych chorób, których nie udaje się zwalczyć, a jedynie można zmniejszyć dolegliwości związane z nimi. Mowa tu o osobach dotkniętych AIDS, chorobą Parkinsona czy też jaskrą. Na rynku farmaceutycznym dostępne są środki pomagające chorym w cierpieniu, które jest nieodłącznym elementem ich schorzeń, jednak przyjmowanie większości z tych leków niesie ze sobą występowanie niepożądanych skutków ubocznych. Firmy produkujące leki oraz laboratoria prowadzące badania nad ich wynalezieniem kierują się tym, by ich odkrycia miały na organizm człowieka możliwie najmniejsze działanie

\footnotetext{
*Uniwersytet Łódzki, Wydział Prawa i Administracji, amalia.habib93@gmail.com.
} 
inwazyjne. Podmioty te wciąż zadają sobie pytanie - czy jest możliwe stworzenie medykamentu, który miałby szerokie spektrum zastosowania w leczeniu wielu chorób przy jednoczesnym ograniczeniu do minimum skutków ubocznych?

\section{CANNABIS - HISTORIA I PODSTAWOWE ZAGADNIENIA}

Cień możliwej odpowiedzi na pytanie pojawił się jakiś czas temu. Od ponad stu lat poruszany jest wątek medycznego zastosowania narkotyków, zarówno miękkich, jak i twardych. W medycynie stosowanie opiatów, między innymi morfiny lub heroiny, miało swój początek pod koniec XIX wieku (UNODC. World Drug Report 2008). Używano ich głównie do zmniejszania bólu. Niektóre narkotyki, takie jak metadon, czyli opioid wytwarzany syntetycznie, są stosowane w ośrodkach leczenia uzależnień do zmniejszenia skutków odstawienia mocniejszych środków odurzających (Pitucha 2015). Morfina jest obecna w medycynie po dzień dzisiejszy jako lek przeciwbólowy podawany w formie roztworu (www.kbpn.gov.pl/portal?id=112444), jednak pozostałe twarde narkotyki zostały uznane za nielegalne $\mathrm{w}$ świetle prawa międzynarodowego, a według społeczeństwa jako źródło degeneracji ludzi.

W drugiej połowie XIX wieku mówiono o wykorzystywaniu miękkich narkotyków wobec niektórych dolegliwości, na przykład konopi używano na problemy z nietrzymaniem moczu lub w celu zmniejszenia napięcia mięśni układu rozrodczego podczas miesiączki lub porodu (Booth 2003). Nie było jednak mowy o tym, by te narkotyki mogły być kiedykolwiek dostępne jako leki całkowicie zwalczające choroby. Zaczęto powoli zastanawiać się nad tym, czy prawdą jest, że wszystkie narkotyki oznaczają samo zło i czy ich jedynym zastosowaniem jest odurzenie się. Według światowych badań, największą szansę na zalegalizowanie ze względu na walory lecznicze mają liście konopi, czyli marihuana. Pojawia się jednak zasadnicze pytanie - jeśli marihuana rzeczywiście ma właściwości lecznicze, to czy władze państw na całym świecie zdecydują się na jej zalegalizowanie? I jak na to zareagują ludzie będący dotąd zagorzałymi przeciwnikami stosowania tego środka?

Cannabis to rośliny ,uprawiane w północnej i środkowej Azji, w Europie, północnej Afryce, Ameryce Północnej i Australii” (Internetowa Encyklopedia PWN. Konopie), jednak głównie używa się odmiany indyjskiej ze względu na proporcje składu chemicznego. Ten rodzaj jest z kolei uprawiany w ,południowo-wschodniej Azji oraz środkowej i północnej Afryce” (tamże). Po wysuszeniu liści konopi oraz żeńskich kwiatostanów otrzymywany jest susz, popularnie nazywany marihuaną (Jędrzejko 2008, 82). Środek ten jest znany od wieków, używany był przez medyków i szamanów. Podawano go ludziom w celu zrelaksowania się i uśmierzania bólu, a szamani wprowadzali się dzięki marihuanie w stan odurzenia, podczas którego mieli podobno łączyć się ze światem duchowym. Współcześnie uznana jest za narkotyk miękki, w większości krajów nielegalny pod względem dystrybucji, hodowania i posiadania. 
Polityka antynarkotykowa wobec marihuany wynika w głównej mierze z negatywnych skutków jej zażywania. Są to między innymi: nadmierna euforia, zaburzenia koordynacji ruchowej, słowotok, halucynacje, a w późniejszej fazie zamknięcie się w sobie, uczucie ciężkości całego ciała, chandra oraz przekrwienie oczu (http://www.kbpn.gov.pl/portal?id=112444). Powodem występowania tego typu zjawisk jest wysoka zawartość procentowa substancji THC, czyli delta-9-tetrahydrokannabinolu. Związek ten jest uwzględniony w polskim systemie prawnym w załączniku nr 2 do ustawy o przeciwdziałaniu narkomanii z 2005 roku jako „substancja psychotropowa grupy I-P mogąca być używana wyłącznie w celu prowadzenia badań" (Art. 33 ustawy z 29.07.2015, poz. 1485), zatem wykluczone są handel, produkcja, posiadanie czy też zażywanie marihuany. W jednej ze swoich publikacji Mariusz Jędrzejko wyróżnia 4 fazy działania cannabis na organizm człowieka po ich zażyciu, są to kolejno stadia: „dobrego samopoczucia i euforii [...], nadwrażliwości zmysłowej [...], ekstatyczne oraz sen i przebudzenie" (Jedrzejko 2008, 83).

Jednak w ciągu ostatnich 20 lat coraz częściej mówi się o pozytywnych skutkach zażywania marihuany, mających duże zastosowanie w medycynie. Oprócz wcześniej wspomnianej pomocy przy uśmierzaniu bólu, co jest wykorzystywane między innymi u osób ze stwardnieniem rozsianym lub rakiem, badania wykazały również zmniejszenie ciśnienia płynu śródgałkowego u chorych na jaskrę, poprawę apetytu przy AIDS oraz zmniejszenie częstotliwości ataków padaczki lekoopornej (Łuniewska 2015). Skąd taka różnica w ocenie skutków zażywania marihuany?

\section{RELACJE MIĘDZY THC I CBD - CO DOBRE, CO ZŁE?}

Otóż to, czy konopie będą wywoływać stan odurzenia czy też będą pomagać chorym w leczeniu różnych schorzeń, wynika z odpowiednich proporcji stężeń między dwiema głównymi substancjami zawartymi w liściach cannabis. Chodzi o wspomniane wcześniej THC oraz CBD, czyli kannabidiol. Ta druga substancja, im większą ma przewagę procentową nad THC, tym bardziej powoduje unieczynnienie psychoaktywnego oddziaływania delta-9-tetrahydrokannabinolu. Mariusz Jędrzejko w swojej publikacji napisał, że „CBD nie jest psychoaktywne, ma wyraźny wpływ na euforyczne działanie THC - redukuje je i wyzwala efekt uspokajający" (Jędrzejko 2011, 139). Skutkiem tego jest minimalizacja odurzenia prawie do $0 \%$ przy wzroście dobroczynnych objawów. Do takich wniosków doszedł znany na całym świecie naukowiec Josh Stanley, od lat starający się wyhodować specjalną medyczną odmianę marihuany, wzbogaconą CBD przy proporcjonalnym zmniejszeniu stężenia THC. Jego osiągnięcia zostały zauważone i wyemitowane w dokumentach CNN Weed i Weed 2, poświęconych działalności Josha Stanleya. Oprócz tego naukowiec otworzył w Kolorado pierwszą placówkę na świecie zajmującą się badaniami nad stworzeniem takiego rodzaju konopi oraz 
powołał stowarzyszenie mające na celu kontrolowanie ,przestrzegania zasad w przemyśle konopi" i wspomagające osoby cierpiące na schorzenia leczone jej medyczną odmianą. Brał też udział w tworzeniu ustawy House Bill 1043, której celem było uregulowanie prawne stosowania marihuany w przypadkach różnych chorób (www.internationalcannabisassociation.com/speaker-lineup/josh-stanley).

Medyczna odmiana konopi jest podawana chorym w różnych formach. Podstawowym środkiem jest ziele w formie suszu, który można dodawać do żywności (niektórym dzieciom podawana jest razem z masłem, by nie odczuwały ,goryczki” ziela) lub skręcać w formie papierosa. Ta druga opcja jest raczej polecana dla dorosłych pacjentów, których dolegliwości nie są związane z układem oddechowym lub pokarmowym, gdyż dym mógłby podrażniać ich organizm. Jest również trzecia opcja, której twórcą jest Rick Simpson. W wyniku własnych badań doprowadził on do spreparowania marihuany w formie olejku, mającego nazwę RSO (Rick Simpson Oil) lub też „łzy feniksa” (Phoenix Tears). Jego głównym celem było wynalezienie środka na raka, jednak z czasem odkrył, że lek pomaga zwalczać wiele innych chorób. Przez swoje osiągnięcie stał się ikoną walki z systemem w celu zalegalizowania marihuany nie tylko w Wielkiej Brytanii, ale i w całej Europie (http://phoenixtears.ca/ricks-page).

\section{DEBATA W STANACH ZJEDNOCZONYCH - PELNA LEGALIZACJA CZY MODEL QUASI-LEGAL?}

Oczywiste jest, że należy rozwiać wątpliwości, czy medyczna marihuana naprawdę nie jest szkodliwa. Dodatkowo pojawia się pytanie, czy zalegalizowanie marihuany może spowodować wzrost jej zażywania przez społeczeństwo oraz czy będzie to wywoływać skutki śmiertelne. O tym, że cannabis można uznać za lek bezpieczny, świadczy między innymi opinia Mariusza Jędrzejki twierdzącego, że dawka śmiertelna dla marihuany i haszyszu jest „nieokreślona”, gdyż „nie stwierdzono śmiertelnych zejść po zażyciu” tych środków (Jędrzejko 2008, 159). W celu wyjaśnienia pozostałych wątpliwości zostały przeprowadzone badania w 50 stanach USA w latach 1999-2010, kiedy medyczna odmiana była legalna tylko w 10 stanach. Okazało się, że tam, gdzie konopie lecznicze były prawnie dostępne, śmiertelność z powodu przedawkowania opioidów, czyli twardych narkotyków, była niższa o 24,8\% niż w stanach, gdzie nie doszło jeszcze do zalegalizowania marihuany medycznej (Bachhuber 2014). Ma to związek z tym, że pieniądze z podatków ze sprzedaży leczniczych konopi w stanach, które unormowały prawnie legalizację konopi, są przeznaczane na akcje edukacyjne i prewencyjne, mające uświadamiać ludzi o niebezpieczeństwie wynikającym z używania twardych narkotyków.

Pierwsze wzmianki o depenalizacji leczniczych cannabis pojawiły się w latach 90., kiedy to mieszkańcy Kalifornii w Stanach Zjednoczonych w 1995 roku 
opowiedzieli się za używaniem konopi do celów medycznych, jednak Agencja do Spraw Walki z Narkotykami (DEA) prowadziła aktywną politykę antynarkotykową wobec przychodni sprzedających taką odmianę marihuany (Henry 2012, 97). Od 1996 roku 18 stanów oraz jeden Dystrykt Kolumbia (inaczej Waszyngton) zdecydowały o zalegalizowaniu medycznych konopi służących zwalczaniu określonych chorób. Każdy z nich ma klauzulę dotyczącą obowiązku, dobrowolności lub braku wymogu prowadzenia przez władze rejestru osób, którym jest zapisywany taki lek. Oprócz tego są dla każdego z regionów prowadzone katalogi schorzeń, wobec których można przepisywać medykament, oraz wykaz zaleceń, które muszą być spełnione, by uzyskać do niego dostęp (Marcoux, Larrat, Vogenberg 2008, 612-617). Jest to dobry system, który łatwo może być kontrolowany przez organy państwowe pod względem zgodności działań szpitali wobec procedur stanowych. Podobnie jest z pacjentami, którzy mają szansę na legalne leczenie, bez konieczności łamania przepisów przez dążenie do leków niedozwolonych przez prawo.

Należy pamiętać, że legalizacja marihuany w celach medycznych nie jest równoznaczna z dopuszczeniem do legalnego obrotu zwykłych liści konopi z wysokim stężeniem THC. Taka sytuacja ma miejsce w Kalifornii, gdzie można zakupić tylko medyczną odmianę w specjalnie wyznaczonych placówkach medycznych, zatem powszechnie mówi się tam o quasi-legal system (Henry 2012, 91), który został ustanowiony na podstawie Proposition 215. Akt ten mieszkańcy stanu przegłosowali wiekszością 56\% w referendum, które zostało przeprowadzone w 1996 roku (Proposition 215, text of the law). Jest to o tyle bezpieczny wariant systemowy, że społecznie brakuje wobec niego sprzeciwu, ponieważ nie prowadzi on do zwiększenia liczby osób uzależnionych od narkotyków, zwłaszcza twardych. Dzieje się tak dlatego, że lecznicza marihuana ma wysokie stężenie CBD, które „wycisza” psychoaktywne działanie THC, czego skutkiem jest brak możliwości odurzenia się po zażyciu medycznych konopi.

Można również nadmienić, że ,zgodnie z danymi z Ministerstwa Spraw Zagranicznych Holandii kraj ten w porównaniu z pozostałymi członkami Unii Europejskiej ma «niewielki odsetek» problematycznych konsumentów twardych narkotyków" (Henry 2012, 74). Oczywiście, tam legalizacja dotyczy nie tylko odmiany leczniczej, lecz mimo to można zauważyć korelację między wprowadzeniem quasi-legalizacji a spadkiem liczby osób sięgających po kokainę czy heroinę.

\section{LIBERALNE PODEJŚCIE URUGWAJU - PIERWSZEGO KRAJU NA ŚWIECIE Z PRZYJĘTYM SYSTEMEM PEŁNEJ LEGALIZACJI MARIHUANY}

Oprócz systemu przyjętego w Kalifornii, istnieją inne warianty prawnych regulacji związanych z obrotem używkami. Przez większość krajów na świecie sytuacja dopuszczająca całkowitą legalizację konopi z niewielkimi ograniczeniami 
jest niemalże niewyobrażalna, ponieważ wielu ludzi uważa taką ewentualność za ogromne zagrożenie dla społeczeństwa. Urugwajczycy jednak zdecydowali się na taką opcję. Według panującego stereotypu Urugwaj jest jednym z najbardziej religijnych krajów na świecie, ale ostatni sondaż przeprowadzony w Ameryce Łacińskiej pokazuje, że stał się „,najbardziej zsekularyzowanym krajem” (http://swiat.newsweek.pl/ile-jest-katolikow-w-ameryce-lacinskiej-newsweek-pl,artykuly,351666,1.html). Decyzja o legalizacji marihuany została podjęta przez lewicowe rządy koalicji Frente Amplio, na czele której stał ówcześnie urzędujący prezydent José Mujica. Dzięki większości parlamentarnej zarówno w Izbie Reprezentantów, jak i w Senacie ustawa została przegłosowana, a po podpisie głowy państwa weszła w życie w połowie 2014 roku (http://www.bbc. com/news/world-latin-america-27265310). Zgodnie z aktem Law No 19.172, obrót konopiami przez obywateli Urugwaju jest ograniczony poprzez ścisłą kontrolę państwową. Przykładowo jedna osoba po wcześniejszym zarejestrowaniu się może miesięcznie mieć zapas nieprzekraczający 40 gramów ziela, a złapani na paleniu w pracy lub będący pod wpływem marihuany podczas kierowania pojazdem zostaną tak samo ukarani jak ci, co prowadzili po spożyciu alkoholu (tamże). Światowy raport ONZ z 2014 roku dotyczący narkotyków wskazuje, że według wyżej wymienionej ustawy obywatele mają prawo do uprawy, produkcji, sprzedaży i używania tej rośliny (UNODC, World Drug Report 2014). Prowadzenie plantacji cannabis o działaniu psychoaktywnym musi być zarejestrowane w Instytucie Regulacji i Kontroli Konopi oraz jest przez instytucję ograniczone ilościowo - limit ten może być zwiększony, jeśli grupa osób utworzy stowarzyszenie, każdy z uczestników otrzymuje legitymację członkowską ułatwiającą prowadzenie ogólnokrajowych rejestrów osób związanych z obrotem marihuaną (Ustawa z 20.12.2013 r. o kontroli i regulacji...).

\section{A CO U NAS? DEBATA POLITYCZNO-PRAWNA W POLSCE}

Po omówieniu bardziej liberalnych rozwiązań należy rozpatrzyć też systemy preferujące penalizację narkotyków zarówno miękkich, jak i twardych. Takim krajem jest między innymi Polska. W najbliższej przyszłości nie ma raczej nadziei na uchwalenie ustawy o ogólnym zalegalizowaniu marihuany, jednak od jakiegoś czasu w naszym kraju coraz więcej środowisk i podmiotów państwowych porusza problem konieczności wprowadzenia zgody na używanie konopi w celach medycznych. I nie chodzi tu tylko o dopuszczenie przeprowadzania testów i badań $\mathrm{z}$ ich użyciem, ale też o to, by wprowadzić ten specyfik farmaceutyczny do leczenia pacjentów z określonymi schorzeniami.

Pierwsze wzmianki o dobroczynnym działaniu medycznej marihuany pojawiły się w Polsce około 2012 roku. Doktor Marek Bachański, specjali- 
sta w dziedzinie pediatrii oraz neurologii dziecięcej i epileptologii z Instytutu Centrum Zdrowia Dziecka w Warszawie, rozpoczął badania na grupie dziewięciu swoich pacjentów. Są to dzieci chorujące na padaczkę lekooporną, w tym ciężki do leczenia zespół Dravet oraz zespół Lennox-Gastauta. Od początku działania lekarza były przyjmowane przez społeczeństwo entuzjastycznie, a ludzie chorujący na inne schorzenia zaczęli mieć nadzieję na ratunek również dla nich. Bachański uważa, że otrzymanie medycznej marihuany w Polsce jest skomplikowaną procedurą, która pochłania dużo cennego czasu. Wszystko odbywa się na zasadzie importu docelowego, polegającego na uzyskaniu zgody od wojewódzkiego lub krajowego konsultanta w zakresie neurologii dziecięcej oraz ministra zdrowia. Następnie lekarz występujący o import leku wypisuje receptę i składa zamówienie w aptece zagranicznej z kraju, gdzie dany lek z marihuaną jest dostępny legalnie, na przykład z Holandii (Relacja filmowa z debaty „Medyczne zastosowanie kannabinoidów w Polsce i na świecie"). Według informacji Polskiej Agencji Prasowej uzyskanych z resortu zdrowia „w latach 2013-2015 MZ wydał [...] 23 indywidualne zgody na sprowadzenie z zagranicy leków na bazie marihuany" (Jakubowski 2015). Jedyny lek na bazie konopi dostępny w Polsce to Sativex, jednak ,może on być stosowany tylko przez pacjentów ze stwardnieniem rozsianym w łagodzeniu objawów spastyczności” (tamże, 2015).

Nie tylko Bachański opowiada się za wprowadzeniem takiej formy leczenia. Osobą bezpośrednio związaną ze sprawą jest Dorota Gudaniec, mama pięcioletniego Maxa cierpiącego na zespół Lennoxa-Gastauta, rzadką postać padaczki lekoopornej. Historię swojego dziecka opowiedziała między innymi podczas debaty dotyczącej medycznych zastosowań marihuany w Polsce i na świecie, zorganizowanej 9 marca 2015 roku przez Polską Sieć Polityki Narkotykowej. Josh Stanley i Marek Bachański również byli obecni na spotkaniu i podzielili się swoim doświadczeniem zawodowym i naukowym. Max jest pacjentem Centrum Zdrowia Dziecka, gdzie jako pierwsza osoba w Polsce został poddany leczeniu marihuaną z wysokim stężeniem CBD. Jego mama stała się dzięki temu osobą bardzo zaangażowaną $\mathrm{w}$ uświadamianie społeczeństwa o dobroczynnych skutkach stosowania marihuany i o konieczności wprowadzenia regulacji prawnych, które umożliwiałyby skuteczne leczenie wielu Polaków.

Za legalizacją opowiada się również były minister zdrowia Marek Balicki, lekarz psychiatra i kierownik Wolskiego Centrum Zdrowia Psychicznego. Według niego marihuana to „lek skuteczny, [...] bezpieczny, bezpieczniejszy od większości leków przeciwbólowych sprzedawanych w Polsce bez recepty" (Relacja filmowa z debaty „Medyczne zastosowanie kannabinoidów w Polsce i na świecie”). Zaznaczył, że zażywanie medycznych konopi niesie ze sobą pewne „działania niepożądane, ale nieporównywalnie mniejsze od leków przeciwbólowych" (tamże), a nawiązując do podjęcia tematu na polu politycznym apeluje, że „należy uniknąć sprzeczności z przepisami ustawy o przeciwdziałaniu narkomanii dotyczącymi stosowania marihuany do celów leczniczych". Podobne zdanie ma 
Monika Płatek, karnistka z Uniwersytetu Warszawskiego. Podczas debaty stwierdziła, że „należy wykorzystać to, co leczy, wtedy, kiedy leczy” (tamże).

Władza ustawodawcza po nagłośnieniu sprawy przez media zapowiedziała rozpoczęcie działań w kierunku depenalizacji stosowania leczniczych konopi w najbliższej przyszłości. Jednym z kroków było wysłuchanie obywatelskie, które odbyło się 9 czerwca 2015 roku w Sejmie. Inicjatorem była wicemarszałek Wanda Nowicka, przy współpracy z Polską Siecią Polityki Narkotykowej. Na spotkaniu z politykami byli obecni między innymi rodzice dzieci wymagających leczenia medyczną marihuaną, w tym rodzice Maxa Gudańca, oraz Marek Bachański (Obara 2015). Podnoszono nie tylko korzyści płynące z zalegalizowania konopi, ale były też osoby wyrażające niepokój z tym związany.

Aktywność polityków została wzmożona po tym, jak w listopadzie 2014 roku Trybunał Konstytucyjny wydał wyrok (o sygnaturze akt SK 55/13) w związku ze skargą konstytucyjną osoby skazanej za posiadanie marihuany na własny użytek w ilości większej niż dozwolona przez ustawodawcę. Mimo iż sędziowie nie uwzględnili roszczeń skarżącego i nie przyznali mu racji względem legalności jego działania, to wyraźnie zaznaczyli, że kwestia zalegalizowania medycznej marihuany musi zostać uregulowana prawnie (Wyrok TK z 4.11.2014). Taka decyzja była podyktowana nawiązaniem do argumentu skazanego, że konopie miał i używał na własny użytek w celach leczniczych. Zgodnie ze słowami sędziego Piotra Tulei „Trybunał w jednej kwestii podzielił stanowisko prezentowane przez skarżącego i podnoszone na rozprawie, mianowicie, że brak w zasadzie uzasadnienia dla wprowadzenia zakazu posiadania i używania marihuany wtedy, gdy byłoby to uzasadnione względami medycznymi” (Zborowski 2014). Oprócz tego Trybunał Konstytucyjny w postanowieniu wydanym 17 marca 2015 roku (o sygnaturze akt S 3/15) uznał „celowość podjęcia działań ustawodawczych zmierzających do uregulowania kwestii medycznego wykorzystania marihuany" (Postanowienie TK z 17.03.2015). Sędziowie podkreślają, że ich postanowienie "nie przesądza o sposobie uregulowania przez ustawodawcę kwestii medycznego wykorzystywania marihuany, zwraca jednak uwagę na potrzebę unormowania tej kwestii” oraz wskazuje „potrzebę zharmonizowania regulacji urzeczywistniających deklarowane przez ustawodawcę cele $\mathrm{w}$ taki sposób, by w analizowanym zakresie realizacja jednego z nich nie prowadziła do całkowitego wykluczenia realizacji drugiego celu" (tamże).

Obecnie są zapowiadane prace parlamentarne nad trzema projektami ustaw mającymi na celu zastosowanie się do zaleceń sędziów Trybunału Konstytucyjnego oraz do próśb obywateli. Swoje pomysły zgłosiła jak dotąd Zjednoczona Prawica przez jej rzecznika posła Patryka Jakiego, Sojusz Lewicy Demokratycznej, partia Kukiz'15 oraz Wanda Nowicka. Każdy z tych projektów uwzględnia dopuszczenie marihuany medycznej do obrotu, aczkolwiek stopień swobody legalizacyjnej różni się w zależności od poglądów projektodawców. Między inny- 
mi Zjednoczona Prawica zgodzi się na depenalizację, jeśli zostaną przeprowadzone wiarygodne badania naukowe potwierdzające ponad wszelką wątpliwość skuteczność leczenia taką metodą. Z kolei wicemarszałek Sejmu Wanda Nowicka dąży do zniesienia karalności hodowania i zażywania konopi na własny użytek, nie tylko ze względów medycznych (Jakubowski 2015).

\section{OCENY LEKARZY I HELSIŃSKIEJ FUNDACJI PRAW CZLOWIEKA}

Oczywiście ważną kwestią jest też stanowisko lekarzy wobec proponowanych rozwiązań. W końcu to oni podejmują faktyczną decyzję o wprowadzeniu danej metody leczenia wobec pacjentów. W ostatnim czasie dużo się mówi o etyce i „sumieniu lekarskim”, które to kwestie nie są jasno sprecyzowane względem tego, kiedy można się na nie powołać, nie łamiąc jednocześnie obowiązku udzielenia pomocy potrzebującym podopiecznym. O etycznych dylematach w zawodzie lekarza wypowiedziała się w swoim artykule Urszula Fiszer, specjalistka neurologii i epileptologii. Jej zdaniem „dla wypełnienia swoich zadań lekarz powinien zachować swobodę działań zawodowych, zgodnie ze swoim sumieniem i współczesną wiedzą medyczną”, a ponadto „lekarz ma swobodę wyboru w zakresie metod postępowania, które uzna za najskuteczniejsze" (Fiszer 2010, 67-68). Powołuje się przy tym na rzymską paremię - Salus aegroti suprema lex esto, która wyraźnie wskazuje, że dobro chorego powinno być dla lekarza jego najwyższym nakazem etycznym (tamże). Można zatem z tego wywnioskować, że lekarz ma prawo wprowadzić w tok leczenia taką metodę, która jest przede wszystkim skuteczna, mimo iż może być postrzegana publicznie za nieetyczną. Takie zdanie o leczeniu marihuaną ma większość osób działających w ramach polityki antynarkotykowej, które uważają, że coś co jest narkotykiem nie może być jednocześnie wykorzystane wobec ludzi jako lek. Światowe badania opinii publicznej również potwierdzają akceptację dla stosowania cannabis w medycynie. Według ankiety przeprowadzonej przez "New England Journal of Medicine" na grupie 1446 lekarzy z 72 krajów i 56 stanów, aż 76\% lekarzy chce wdrożenia leczenia medyczną marihuaną (Adler, Colbert 2013).

Swoje zdanie w sprawie potrzeby uregulowania prawnego wyraziła Helsińska Fundacja Praw Człowieka w swojej analizie pt. Medyczna marihuana - czas na reakcję ustawodawcy. Autorzy nawołują do zastosowania się parlamentarzystów do postanowienia sygnalizacyjnego Trybunału Konstytucyjnego. Wskazywany jest argument, iż przez ograniczenie dostępu do marihuany medycznej naruszane są podstawowe prawa i wolności, w tym ,zapewnienie prawa do ochrony zdrowia" (Kubaszewski, Warso 2015, 1). Ponadto organizacja w swojej opinii uważa, 
że należy „rozważyć konieczność wprowadzenia zmian w przepisach, tak aby zagwarantować skuteczną terapię wszystkim pacjentom cierpiącym z powodu bólu". Jednocześnie zaleca usunięcie sprzeczności między ustawami o zawodach lekarza i lekarza dentysty z 1996 roku oraz o prawach pacjenta i Rzeczniku Praw Pacjenta z 2008 roku, gdzie występuje rozbieżność między wprowadzeniem w tok leczenia dostępnych metod zgodnie z aktualną wiedzą lekarza a stosowaniem „świadczeń zdrowotnych zapewniających łagodzenie bólu” tylko dla „,pacjentów w stanie terminalnym”, bez uwzględnienia innych grup chorych osób (tamże, 4).

\section{PODSUMOWANIE}

Podsumowując powyższe argumenty i opinie uważam, że sprawa wprowadzenia legalizacji medycznej marihuany jest kwestią czasu nie tylko w Polsce, ale także w większości krajów na świecie. Należy przeprowadzać badania obejmujące szerokie spektrum schorzeń, które mogłyby być leczone konopiami. Pomogłoby to w uwiarygodnieniu dobroczynnego działania tego specyfiku. Społeczeństwo w coraz większym stopniu udziela poparcia dla wprowadzenia takiej metody medycznej. Jak można się domyślić, największy entuzjazm wypływa ze środowisk popierających pełną legalizację marihuany, w nadziei, że depenalizacja odmiany medycznej pociągnie za sobą dopuszczenie do obrotu zwykłych konopi. Dlatego ustawodawca powinien dokładnie przeanalizować proponowane rozwiązania prawne, tak by nie stworzyć ,szarej strefy” dla stosowania marihuany w celu odurzania. Jednym z takich kroków mógłby być zapis, że leczeniem cannabis byłyby objęte osoby, które mają za sobą nieefektywne stosowanie innych dostępnych metod zwalczania ich schorzeń, by nie doprowadzić do nadużywania tego rozwiązania. Związana z tym byłaby rejestracja chorego jako osoby stosującej taki medykament. Dodatkowo można wprowadzić obowiązkowe badania psychologiczne, które wykluczałyby skłonności do uzależnień lub manipulacji swoim stanem zdrowia. Z takim problemem początkowo borykał się stan Kolorado, gdzie ludzie przychodzili po receptę na medyczną marihuanę z powodu bólu głowy lub potrzeby odprężenia się po ciężkim dniu. Wynikało to z błędnego przeświadczenia, że leczniczymi konopiami można się odurzyć. Kolejnym rozwiązaniem, które przyniosłoby też korzyści dla państwa, byłoby przekazywanie środków ze sprzedaży tych leków na akcje prewencyjne i zapobiegające narkomanii oraz na rzecz organizacji pomagających osobom uzależnionym od twardych używek, między innymi od dopalaczy lub opiatów. Spełnienie szeregu tego typu postulatów pomogłoby wielu potrzebującym pomocy ludziom, których jedynym celem i marzeniem jest odzyskanie utraconego zdrowia, a idąc za opinią Helsińskiej Fundacji Praw Człowieka uważam, że ochrona tego aspektu życiowego powinna być prioryte- 
tem dla władz państwowych, tak jak to wskazuje art. 68 ust. 1 Konstytucji RP. Dlatego należy rozpocząć możliwie jak najszybciej działania, które spełniłyby oczekiwania obywateli do godnego życia.

\section{BIBLIOGRAFIA}

Adler, Jonathan, James Colbert. 2013. "Medicinal Use of Marijuana - Polling Results". New England Journal of Medicine 368: e30. www.nejm.org/doi/pdf/10.1056/NEJMclde1305159 [dostęp 30.07.2015].

Bachhuber, Marcus. 2014. Lower Opioid Overdose Death Rates Associated with State Medical Marijuana Laws. M.D. of the Philadelphia Veterans Affairs Medical Center, and colleagues, JAMA Intern Med. http://archinte.jamanetwork.com/article.aspx?articleid=1898878 [dostęp 8.02.2016].

Booth, Martin. 2003. Cannabis: A History. London: Picador.

Fiszer, Urszula. 2010. „Często spotykane dylematy etyczno-prawne w praktyce neurologa”. Polski Przeglad Neurologiczny. Tom 6, supl. A: 67-68.

Henry, Michel. 2012. Narkotyki. Dlaczego legalizacja jest nieuchronna? Warszawa: Czarna Owca.

Internetowa Encyklopedia PWN. Konopie. http://encyklopedia.pwn.pl/haslo/konopie;3925121.html [dostęp 27.07.2015].

Jakubowski, Grzegorz. 2015. MZ: leki na bazie marihuany można sprowadzać do Polski. PAP. $\mathrm{http} / /$ www.pap.pl/palio/html.run?_Instance $=\mathrm{cms}$ _www.pap.pl\&_PageID=1\&s=infopakiet\&$\mathrm{dz}=\mathrm{kraj} \& \mathrm{idNewsComp}=\&$ filename $=\&$ idnews $=223487 \&$ data $=\&$ status $=$ biezace $\&$ CheckSum=-178124976 [dostęp 30.07.2015].

Jędrzejko, Mariusz. 2008. Narkotyki: Vademecum. Warszawa: Pedagogium.

Jędrzejko, Mariusz. 2011. Marihuana fakty: marihuana mity. Wrocław: Wrocławskie Wydawnictwo Naukowe ATLA 2.

Kubaszewski, Piotr, Zuzanna Warso. 2015. Medyczna marihuana - czas na reakcję ustawodawcy. Problem nieskutecznego leczenia bólu w kontekście konieczności uregulowania w polskim prawie medycznego wykorzystania marihuany. Helsińska Fundacja Praw Człowieka. Analizy i rekomendacje 8/2015: 1. http://www.hfhr.pl/wp-content/uploads/2015/05/hfpc_analizy_i_rekomendacje_82015.pdf [dostęp 30.07.2015].

Łuniewska, Luiza. 2015. Marihuana ma właściwości lecznicze przydatne w terapii raka, stwardnienia rozsianego, jaskry. www.poradnikzdrowie.pl/zdrowie/medycyna-niekonwencjonalna/ marihuana-wlasciwosci-lecznicze-przydatne-w-terapii-raka-sm-jaskry_34974.html [dostęp 28.07.2015].

Marcoux, Rita, Paul Larrat,_Randy Vogenberg. 2008. "Medical Marijuana and Related Legal Aspects". Pharmacy \& Therapeutics 10 (38): 612-617.

Obara, Marcin. 2015. Lekarze i pacjenci apeluja o dostęp do medycznej marihuany. PAP. http:// www.pap.pl/palio/html.run? Instance $=\mathrm{cms}$ www.pap.pl\& PageID $=1 \& \mathrm{~s}=$ infopakiet\&$\mathrm{dz}=$ nauka\&idNewsComp $=213083 \&$ filename $=\&$ idnews $=216394 \&$ data $=\&$ status $=$ biezace $\&$. CheckSum=618713052 [dostęp 30.07.2015].

Oficjalna strona internetowa International Cannabis Association. www.internationalcannabisassociation.com/speaker-lineup/josh-stanley/ [dostęp 27.07.2015].

Oficjalna strona internetowa Krajowego Biura Do Spraw Przeciwdziałania Narkomanii. www.kbpn. gov.pl/portal?id=112444 [dostęp 27.07.2015]. 
Oficjalna strona internetowa miesięcznika Newsweek Polska. 2014. http://swiat.newsweek.pl/ile-jest-katolikow-w-ameryce-lacinskiej-newsweek-pl,artykuly,351666,1.html/ [dostęp 29.07.2015].

Oficjalna strona internetowa organizacji Ricka Simpsona Phoenix Tears. http://phoenixtears.ca/ ricks-page [dostęp 27.02.2015].

Oficjalna strona internetowa Telewizji BBC News. 2014. http://www.bbc.com/news/world-latin-america-27265310 [dostęp 29.07.2015].

Pitucha, Agata. 2015. Rodzaje narkotyków i ich działanie. Oficjalna strona internetowa Instytutu Psychologii Zdrowia Polskiego Towarzystwa Psychologicznego. www.psychologia.edu.pl/ czytelnia/126-uzalenienie/1408-rodzaje-narkotykow-i-ich-dzialanie-agata-pitucha.html/ [dostęp 28.07.2015].

Postanowienie Trybunału Konstytucyjnego z 17.03.2015 (niepubl.)

Proposition 215, text of the law. Oficjalna strona internetowa Departamentu Zdrowia Publicznego w Kalifornii.www.cdph.ca.gov/programs/MMP/Pages/CompassionateUseact.aspx [dostęp 27.07.2015].

Relacja filmowa z debaty „Medyczne zastosowanie kannabinoidów w Polsce i na świecie”. Oficjalna strona internetowa Polskiej Sieci Polityki Narkotykowej. http://politykanarkotykowa.pl/ artykul/filmowa-relacja-debaty-medyczne-zastosowanie-kannabinoid-polsce-i-wiecie [dostęp 30.07.2015].

UNODC. World Drug Report 2008. United Nations Publication Sales No. E.08.XI [dostęp 28.07.2015].

UNODC. World Drug Report 2014. United Nations Publication Sales No. E.14.XI.7 [dostęp 28.07.2015].

Ustawa z 20.12.2013 r. o kontroli i regulacji statusu przewozu, produkcji, zakupu, magazynowania, marketingu i produkcji marihuany i jej pochodnych w Urugwaju Nr 19.172, Art. 28, pkt C i D. Wyrok Trybunału Konstytucyjnego z 4.11.2014 r. Dz. U. 2014, poz. 1568.

Zborowski, Bartłomiej. 2014. Trybunat Konstytucyjny: Przepisy o karaniu za uprawę konopi - konstytucyjne. PAP. www.pap.pl/palio/html.run?_Instance=cms_www.pap.pl\&_PageID=1\&s=infopakiet $\& \mathrm{dz}=\mathrm{kraj} \& \mathrm{idNewsComp}=\&$ filename $=\&$ idnews $=186552 \&$ data $=\&$ status $=$ biezace $\&$ _ CheckSum=-2009810509 [dostęp 30.07.2015].

\title{
Amalia Habib
}

\section{MEDICAL ASPECT OF LEGALIZING SOFT DRUGS - THREAT OR OPPORTUNITY FOR EFFECTIVE TREATMENT?}

\begin{abstract}
Nowadays medical use of marijuana is being brought up in public more often than in the recent years. The latest clinical trials confirm its healing effect on a human body in a fight against different kinds of diseases, which before its legalization were incurable or debilitating. In the world more and more countries legalize or quasi-legalize cannabis trade. The Polish legal system does not currently allow legalization of cannabis, however, the public opinion is voicing its approval for introducing legal, medical usage of marijuana, and public institutions agitate the government for regulation of this issue. Anti-drug communities speak only about negative consequences of using soft drugs. It is worth doing a balance of gains and losses and reanalyzing research to resolve the dilemma - is marijuana the pure evil or is it a real chance for effective treatment?
\end{abstract}

Keywords: medical cannabis, cannabis, medical cannabis policy, marijuana use, legalization. 